\begin{tabular}{|c|c|}
\hline $\begin{array}{c}\text { ASIAN SOCIAL WORK } \\
\text { JOURAL } \\
\text { (ASW) }\end{array}$ & Asian Social Work Journal (ASWJ) \\
& Volume 4, Issue 2, March 2019 \\
& e-ISSN : 0128-1577 \\
& Journal home page: \\
& www.msocialwork.com \\
\hline
\end{tabular}

\title{
Coping Strategy Enhancement for Families Who Have Children with Thalassemia Through Family Counseling at Sukabumi Thalassemia Foundation
}

\author{
Meiti Subardhini' ${ }^{1}$, Rini Hartini Rinda A $^{1}$, Elin Herlina ${ }^{1}$ \\ ${ }^{1}$ Sekolah Tinggi Kesejahteraan Sosial Bandung, Indonesia \\ Corrrespondence: Meiti Subardhini (meiti.subardhini@gmail.com)
}

\begin{abstract}
Family copyng strategy is one of the factors so that families with thalassemia children can survive and function properly. The purpose of this study is to determine whether family counseling had an effect on improving family copyng strategy, by identifying 1). What are the characteristics of children and families in the Sukabumi branch thalassemia foundation? 2). What is the process of family counseling? 3). What are the results of implementing family counseling? This study used a qualitative approach with the action research method. Three families with thalassemia children with main data collection techniques by providing indeepth interview, supplemented by observations and study documentation. The results showed that children with thalassemia had transfused between 3 to 10 years, and routinely performed transfusions every week to every month. Family counseling provides solutions to problems faced by families as an effort to improve family strategy copyng. Active families seek support from extended families, doctors and friends. Families always think positively and organize themselves not to display negative emotions and improve spiritual life. The conclusion of this study indicates that family counseling can have a positive influence on improving family copyng strategy. Family counseling as an intervention that involves all family members also strengthen relationships between family members. The practical implication of the family counseling process requires commitment from all family members, the willingness to openly convey what is felt and thought.
\end{abstract}

Key words: coping strategy, family counseling, children with thalassemia

\section{Introduction}

Thalassemia is a blood disorder caused by genetic factors and causes proteins in red blood cells (hemoglobin) not to function normally. This condition is caused because the spinal cord is unable to produce red blood cells. As a result, sufferers often experience anemia or lack of blood, so they must continue to do blood transfusions. The number of people with thalassemia major in Indonesia continues to increase. At present there are 7,238 sufferers. Thalassemia major sufferers are characterized by the need for regular blood transfusions. The highest number is in West Java Province reaching 42 percent of all sufferers. Most sufferers are in the age range of children and adolescents.

There is no cure for thalassemia, but it can be managed through healthy food intake and a healthy lifestyle. But not a few children with thalassemia who become less enthusiastic, often weak and feeling sad because they have to constantly do blood transfusions, so that children withdraw from their social environment. 
Family is the main source system for children with thalassemia (support system). Therefore the family must have adequate function capacity. Family strategy is one of the determining factors so that families with thalassemia children can survive and can still have a good quality of life. According to Lazarus (1984) in Safaria $(2012 ; 96)$ states that:

"Coping is a strategy for managing behavior to the most simple and realistic problem solving, functioning to free yourself from real or unreal problems, and coping is a cognitive and behavioral effort to overcome, reduce and resist demands (distress demands)".

Based on the description above, then coping strategy is any effort made by individuals to overcome problems or get out of problems in order to adjust to changes that occur.

The contribution of social workers, especially social workers in the health / medical field is closely related in this study. Medical social workers can play one of them as counselors to children and families to improve family coping strategies. One of the right techniques for improving coping mechanisms is Family Counseling. Family counseling can be defined as an interactive process that seeks to help families get homeostatic balance so that family members can feel comfortable / compfortable (Hasnida S.Psi, 2002).

The purpose of this research was to determine whether the application of family counseling can influence the improvement of positive coping mechanisms in children with thalassemia. By reviewing). What are the characteristics of children with thalassemia and their families? 2). How do family counseling take place? 3). What are the results of implementing family counseling? This research was conducted on thalassemia children who were at the Sukabumi Branch Thalassemia Foundation.

Coping strategy of the family in this research was reviewed from the aspects of coping strategy according to Carver (1989), namely:

i. Self-activity, children take action to try to eliminate or deceive the causes of stress due to separation or correcting the consequences directly.

ii. Planning, thinking about how to overcome the causes of stress because of the separation between, among others, by making a strategy to act thinking about the steps that need to be taken in dealing with a problem.

iii. Self control, children limit their involvement in competition or competition activities and do not act in a hurry.

iv. Looking for social support that is instrumental, namely as advice, assistance or information.

v. Looking for emotional social support, namely through moral support, sympathy or understanding.

vi. Acceptance, something that is full of stress and circumstances that force it to overcome the problem.

vii. Religiosity, children's attitudes calm and resolve problems religiously.

This research is expected to contribute to families with thalassemia children to have a positive coping strategy through counseling to families so as to improve the quality of life for children with thalassemia.

\section{Methodology}

The type of research used is action research with the post-positivist social work research paradigm. Through this post-positivistic paradigm, researchers explore data holistically and comprehensively in accordance with the reality in the field. Through this research design it is expected that the research activities carried out will be able to have a real impact on families with thalassemia children. According to Ernest T. Stinger (2007: 8) there are 3 main aspects in action research namely Look (see), 
Think (thinking) and Act (action). Operationalization in action research can be briefly described in 3 stages, namely:

Stage I: Look (See) - Look is a stage to make a picture of the family situation with children with thalassemia, through developing an intervention plan to improve the ability of family strategy copyng with children with thalassemia

Stage II: Think (Think) - At this stage the researcher analyzes the family situation. In this study researchers used alternative Problem Analysis - Antecedents and Consequences, researchers have a comprehensive pattern of thinking about the causes and consequences of client conditions.

Stage III: Act (Actions) - The Act (action) consists of three stages, including planning activities to design family counseling practices, 2). Implementation of the counseling process. 3). Evaluation by identifying signs of behavior change experienced by the family after the intervention is compared to before getting an intervention.

The following is an overview of the action research process, from sources: Ernest T. Stinger (2007: 9), as follows:

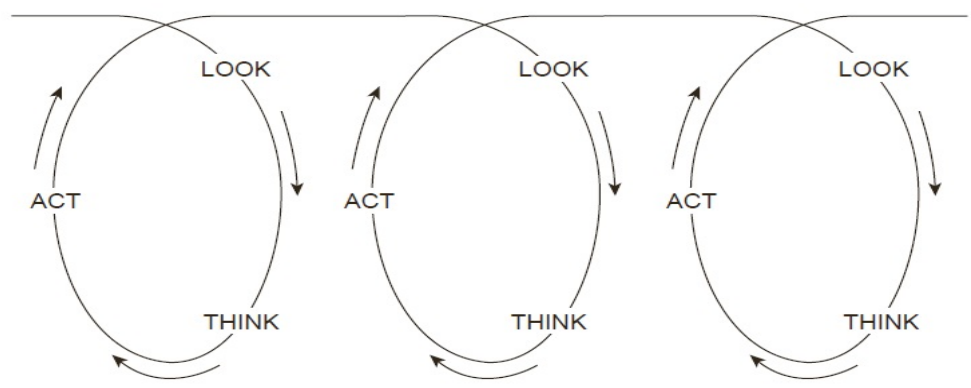

Chart 1.1: Main Flow of Action Research

Data sources were obtained through purposive sampling technique. Primary data sources are mothers, fathers, children, nurses and doctors. Secondary data sources are obtained from documentation studies or through data from previous studies, scientific books and magazines, sources from archives and other documents.

Data collection was done through in-depth interviews / family counseling process for children with thalassemia, their families, doctors and nurses at the Thalassemia Foundation, Sukabumi Branch. Another technique is participatory observation carried out by observing and participating in the intervention activities carried out.

The validity test of the data in this research includes credibility test (internal validity), transferability (external validity), dependability (conformity) and conformability (objectivity). Data collected through data collection techniques, analyzed qualitatively. The data analysis technique used follows the model delivered by Miles and Hiberman as quoted by Sugiyono (2007: 245-253) as follows: 1). Data Reduction, by selecting, determining focus, simplifying, summarizing, and changing the form of raw data in field notes. 2). Data Presentation, so that the research results are easy to read and understand accompanied by photos, charts, graphs and tables. 3). Draw conclusions / verify data 


\section{Result}

\section{Characteristics of thalassemia children and their families}

Table 1: Characteristics of thalassemia children and their families

\begin{tabular}{|c|c|c|c|c|c|c|c|}
\hline No & Name & Gender & Education & $\begin{array}{l}\text { Name of } \\
\text { Parents }\end{array}$ & Educat & tion & Occupation \\
\hline \multirow[t]{3}{*}{1} & $\begin{array}{l}\mathrm{R} \\
(11 \text { years } \\
\text { old) }\end{array}$ & $\operatorname{Pr}$ & 5 th grade & $\begin{array}{l}\text { RH } \\
\text { (35 years old) }\end{array}$ & $\begin{array}{l}\text { Senior } \\
\text { school } \\
\text { graduate }\end{array}$ & High & Ojeg \\
\hline & & & & $\begin{array}{l}\text { Ibu FE } \\
\text { (33 years old) }\end{array}$ & & & housewife \\
\hline & & & & & $\begin{array}{l}\text { Junior } \\
\text { school } \\
\text { graduate }\end{array}$ & High & \\
\hline \multirow[t]{3}{*}{2} & $\begin{array}{l}\text { A } \\
\text { (5 years old) }\end{array}$ & $\mathrm{Lk}$ & TK B & $\begin{array}{l}\text { RH } \\
\text { (35 years old) }\end{array}$ & $\begin{array}{l}\text { Senior } \\
\text { school } \\
\text { graduate }\end{array}$ & High & Ojeg \\
\hline & & & & $\begin{array}{l}\text { Ibu FE } \\
\text { (33 years old) }\end{array}$ & & & housewife \\
\hline & & & & & $\begin{array}{l}\text { Junior } \\
\text { school } \\
\text { graduate }\end{array}$ & High & \\
\hline 3 & $\begin{array}{l}\text { YS } \\
\text { (11 } \\
\text { old) }\end{array}$ & $\mathrm{Lk}$ & 5th Grade & $\begin{array}{lr}\text { ibu } & \text { JW } \\
\text { years } & (48 \text { old })\end{array}$ & $\begin{array}{l}\text { Senior } \\
\text { school } \\
\text { graduate }\end{array}$ & High & Ojeg \\
\hline \multirow[t]{2}{*}{4.} & $\begin{array}{l}\text { RA } \\
\text { (11 years } \\
\text { old) }\end{array}$ & $\mathrm{Lk}$ & 5th Grade & $\begin{array}{l}\text { Bapak AJ } \\
\text { (38 years old) }\end{array}$ & $\begin{array}{l}\text { Junior } \\
\text { school } \\
\text { graduate }\end{array}$ & High & $\begin{array}{l}\text { Factory worker } \\
\text { housewife }\end{array}$ \\
\hline & & & & $\begin{array}{l}\text { Ibu RM } \\
\text { (35 years old) }\end{array}$ & $\begin{array}{l}\text { Junior } \\
\text { school } \\
\text { graduate }\end{array}$ & High & \\
\hline
\end{tabular}

\section{Counseling Process Informants 1 (Mr. RH's family and FE's mother) \\ Background}

$\mathrm{R}$ is born with a normal-looking physical condition. When they are 6 months old, their children often get sick. If they pay attention for a period of a week, it's only healthy for about 2 days and the rest is sick. Finally after being checked into the hospital several times it turned out that their child suffered from thalassemia, by requiring a blood transfusion every two weeks.

Blood transfusion can last a full day because there are two processes that they undergo, namely blood transfusion first, after the blood runs out and then connected by inserting intravenous fluids.

When the first child of the respondent stepped on 5 (five) years, Ms. F became pregnant again with her second child and their second child experienced the same condition as their first child who suffered from thalassemia. 


\section{Counseling}

\section{Building Relationships}

The initial stage of counseling is building relationships / trust (trust building). The informant seemed to accept with pleasure, even immediately told about the family's condition and especially the illness that the child experienced openly. At the beginning of the good introduction of the father $(\mathrm{R})$ Mother $(\mathrm{F})$ and the two children welcomed the arrival of the researcher. They answered all the questions of the researchers with great enthusiasm, even telling stories without hesitation about everything they felt and experienced with the researchers.

\section{Disclosure/Depth Search}

Aspects of Self-Activation in Facing Children with Thalassemia: Since knowing their child has thalassemia, $\mathrm{R}$ was quite active in asking the doctor about both thalassemia about the causes, consequences and how to overcome it, and never digging in information from other sources. Sukabumi.

Aspects in Overcoming Thalassemia : $\mathrm{R}$ always strives to make the best plan of action that they are able to treat their children including keeping their two transfusion schedules and trying to help children in their daily activities: preparing school needs, eating, drinking and needing an examination at the hospital. Even so, R often feels hopeless, like the following expression:

“ Abdimah sok sering nangis bu.., terutami wengi-wengi bari ningalikeun barudak nu nuju barobo teh sok cirambai. Kumaha nasib murangkalin sareng kulawargi abdi kapayunna... asa putus asa abdimah bu.."

$\mathrm{R}$ is also always filled with anxiety as quoted in the interview as follows:

"seueur pisan kahariwang abdimah bu, ngemutan kondisi barudak, ditambih ku ngemutan biaya hirup sadidinten oge pusing teu acan kanggo berobat ka rumah sakit"

The statement above shows that $\mathrm{R}$ always feels uneasy in his life. $\mathrm{R}$ also revealed to researchers that he often felt sad and anxious about the fate of his children in the future, because he had often seen children with thalassemia who died.

Aspects of Self-Control in Facing Children with Thalassemia: $\mathrm{R}$ is less able to introspect and improve things in him, tends to always blame the situation, less able to control himself. Feeling uneasy with the condition of his child's illness, and sometimes soluble in emotions, as he saida :

"Upami murangkalih nuju rewel, sagala kedah diturutkeun abdimah kadang sok ngambek malih dugi ka nangis bakat ku keuheul. Pernah sakali waktosmah diciwit eta murangkalih teh dugi ka nangisna.

Furthermore, R conveyed the following:

"murangkalih thalasemia mah benten bu sareng murangkalih nu sanes sagalarupi teh kedah diturutkeun wae. Upami teu diturutkeun teh ngambek. Awon adat dua duana oge. Kapaksa wae sok diturutkeun wae kahoyongna. Tapi nuju teu aya acismah sok kaserengan abdi oge"

From the statement $\mathrm{R}$, it appears that $\mathrm{R}$ in the face of the two children sometimes lost control and overflowed his emotions with his two children.

Aspects of Seeking Instrumental and Emotional Social Support in Facing Children with Thalassemia : $\mathrm{R}$ is quite active in seeking social support, often asking friends who have the same experience to heal 
their children. $\mathrm{R}$ also often asks for support from extended families regarding both their illness and financial condition, also always asks for guidance from a doctor. But $\mathrm{R}$ is still reluctant to ask for help from friends or neighbors. $\mathrm{R}$ is quite active in seeking social support, often asking friends who have the same experience to their children. $\mathrm{R}$ also often asks for extended family regarding both their illness and financial condition, also always asks for guidance from a doctor. But it is still reluctant to ask for help from friends or neighbors, like the following phrase

Self-acceptance of respondent aspect in facing children with Thalassemia: $\mathrm{R}$ considers that at this time the healing of children is something that must be prioritized so that it always tries to undergo all the treatment processes. One of the support and solace is the awareness that there are many other families with the same fate.

Aspect of Respondent Religiosityin facing children with Thalassemia: $\mathrm{R}$ is currently trying to get closer to God in the process of healing his child, following religious activities in his home environment, also always praying to be given ease in treating his child and undergoing his day.

\section{Alternative Solutions / Agreement to act}

Agreement to act in the Aspect of Self-Activation in Facing Children with Thalassemia: The aspect of self-activity in dealing with children with thalassemia which is almost never done by $\mathrm{R}$ is to seek information about thalassemia from other sources (books and the internet), whereas to enrich insight into thalassemia it is recommended to seek information from various sources.

Agreement to Act in Aspects of Planning in Overcoming Thahasemia: At this stage the researcher invites R to: think positively with all the situations it faces, and live a calm life, keep trying the best.

Agreement to act in the Aspect of Self Control in the Face of Children with Thalassemia: At this stage the researcher invites $\mathrm{R}$ to: Learning to organize themselves and lots of introspection on their actions and their impact on children, as well as being calm and not provoked by emotions when children behave unexpectedly.

Agreement to act in the Aspect of Seeking Instrumental and Emotional Social Support in Facing Children Thalassemia: At this stage the researcher invites $\mathrm{R}$ to:

i. Keep in contact and communication and guidance from friends, relatives, to get support

ii. Asking for help from friends or relatives if you experience difficulties in dealing with children with thalassemia.

iii. Be more open to family and friends about the burden of their thoughts and feelings.

iv. Ask for support / moral reinforcement from family / friends.

Agreement to act in the Aspect of Respondents' Self-Acceptance in Facing Children with Thalassemia: At this stage the researcher invites $\mathrm{R}$ to: Accepting the conditions of the two children as a provision from God and going through the days calmly and full of gratitude

Agreement to act in Respondents' Aspects of Religiosity in Facing Children with Thalassemia: The researcher invited $\mathrm{R}$ to get closer to God Almighty in the process of healing his child, as well as increasing the frequency of attending religious activities.

\section{Counseling Process Informant 2 (Keluarga Ibu JW)}

\section{Background}

Ms. JW is a housewife with 3 children, the first child of a 16-year-old girl in grade 1 vocational school, the second child of an 11-year-old YS grade 5 school who is a child with Thalassemia, the third child of a 7-year-old male sits in class 1 Elementary school. A day, JW's mother worked selling snacks, once 
as an ojeg driver. JW's husband died 2 years ago, so he worked hard to support his children. The living conditions are very worrying, with just enough income (Rp. 15,000 to 25,000) every day to pay for rented houses, school fees for children as well as daily needs and for the costs of their second child (YS) suffering from Thalassemia for blood transfusion.

\section{Implementation of family counseling}

\section{Building Relationship}

In the early stages the counseling process was aimed at building trust / building so that the counseling process for the next stage could run smoothly. In this process, the researcher introduces himself to the informant (mother and child) and explains the purpose of the arrival / research that will be conducted. The informant seemed to accept with pleasure, even immediately told about the family's condition and especially the illness that the child experienced openly. The informant seemed happy to be invited to chat, maybe they had not been invited by the story so far so this counseling was used as a mechanism for catharsis. With his eyes glazed with glass, JW's mother said:

“ bu tidak apa apa yaa kita baru kenal saya sudah ingin bercerita banyak tentang kondisi keluarga saya, selama ini saya tidak tahu harus bercerita pada siapa...”.

Likewise with his son (YS), although a bit closed but occasionally he conveyed the answer and also told me about the illness that happened to him. The point is at this stage researchers, feel able to build relationships well, so that the counseling process can take place well.

\section{Disclosure / Depth Search}

At this stage the counseling process is directed to explore information related to the history of thalassemia experienced by his son (YS), problems encountered and efforts made by the family to deal with the problem.

JW only found out that his son (YS) had thalassemia about 4 years ago when YS was in the second grade of elementary school, at that time YS seemed lethargic and unenthusiastic, even in school he often fainted and didn't want to take part in any activities. Especially if he is at home working just sleeping and lazy, his face is pale and his body is limp. Finally YS was examined intensively and found out that she had thalassemia.

According to the examination of the thalassemia doctor who experienced his son came from a genetic element that decreased from his mother's father (there was a blood match between the mother and her father). At the beginning of knowing his son was a child with Thalassemia, the family including JW's mother was very sad, especially after getting an explanation from the doctor that this disease had no cure and would be felt for a lifetime by his son, besides that he received information that the child with Thalassemia was usually not aged long. At that time all the families were sad and felt sorry for YS. The only one in the family who was able to provide enthusiasm and support was her husband (YS's father), he always thought positively about the illness his child had experienced : " there is not one incurable disease, everything will be fine ... God will definitely help us ". Besides that, her husband often also gives reinforcement to other families how to treat YS. But unfortunately the two years that YS's father died due to illness. JW was very devastated and felt he lost his grip, as a household head who had been providing reinforcement to the family.

After her husband died JW tried to find information about treatment for her child, especially after the family decided to move to the city of Sukabumi. Next, find the right school for their children, find work, seek help when in a very urgent situation. All problems faced are related to the diseases faced by his son, also the problem of meeting household needs.

In an effort to fulfill family life and attention to their sick children, JW often feels sad, anxious and sometimes even hopeless, especially considering the future of their children who might not live long. 
He often swallowed his sadness, because there were no relatives in Sukabumi, he was a migrant from Nias Regency, North Sumatra Province. Support from a large family should be quite meaningful, but conditions do not allow it. Therefore, he hopes that there will be assistance both physically and psychologically from the surrounding environment, both neighbors and members of the Sukabumi branch (POPTI) branch of the Indonesian Parents Association, which is very meaningful.

"I really hope other people understand us, starting with the mother who rents her house to me, often paying late, church friends, friends at POPTI and all who know me, even though sometimes it's embarrassing to beg for relief, ask for help etc ... but I strengthened it for the sake of my children ".

The assistance is not just material, sometimes I and other children feel confused how I should deal with YS. Another problem JW felt too, was to seek alternative medicine to cure his child.

"I feel God created the world with all his wealth must be aimed at the good of his people, so I feel there are drugs stored in plants for healing my child, so I did not stop asking questions and find out about what alternative medicine is suitable for my child's recovery"

While from YS there were some things that were felt as a problem, he felt that saddened by his pain because his school activities were disrupted, not free to play and joke, the lesson was left behind because he had to have a blood transfusion. However, he remains optimistic about his recovery even with a loud voice he says : "I want to be a police officer, so that I can help mother and other people", when asked what his goals in the future.

YS also felt sad because he could not help his mother to find money or help other homework. Sometimes YS also likes to feel jealous of his friends who can move as he wishes, but beyond that all YS does not feel ashamed of the conditions they experience, while shaking his head he says: "not shy, why should you be ashamed", he said with certainty.

Another problem that always becomes his mind is that when waiting for transfusion is complete, you have to wait up to 8 hours, so every time you face a transfusion day, you don't have the spirit.

\section{Alternative Solutions / Agreement to act}

From the problems he had felt so far, through this counseling he finally found several solutions to be implemented. JW opened his mind that the knowledge of Thalassemia that he had known so far needed to be improved, so far the information was limited from the management and members of POPTI, for this information search would also be expanded by looking for info in various print and electronic media with technological sophistication now through his biggest child already entered high school.

Another thing that will be done is to seek support from friends, neighbors and family even if only by telephone, moreover, they will look for other source systems, especially psychological support that has been very minimal so far. After being told that there are many professions that can be invited to counseling in addition to social workers, psychologists and maybe at the hospital where POPTI takes shelter there is a special part for this.

\footnotetext{
"Ooh I see, Ma'am ... I just found out, later I asked the hospital staff or I suggested POPTI to provide people to talk to, confide in the core, ma'am ... I need it, so I don't get confused and confused myself..".
}

Thus JW's statement was told about the role of the counselor that was widely available in the community. Other solutions that will be carried out are more calm, positive thinking and not easy emotions for healing children, this will be done: 
"I often think that is not not about children, often feeling the time has come, even though I am also aware of the age of God only knows ... it must be removed from my mind ... the point must be positive and optimistic for the future of the child ".

JW also felt that all this time he had not been closer to the above, because he was busy getting a living for his family often spending Sunday for church. For this reason, he also arranged his time and reminded his children to get closer to God Almighty. JW spoke with full awareness:

"that all of that is at the top of the power, so it's time for me to return it to the one above ... many other people have more severe problems than me ... so I still have to be thankful "..

Besides that, through this counseling, researchers also tried to explore problem solving for their children who felt poor, sad and not excited when doing transfusions, through the transfer of their children's hobbies, so that the transfusion process could run pleasantly. :

"actually his hobbies are playing football, before before being seriously still transfused once a month YS still often plays football with his friends even if only for a while, but now his condition is declining so it is no longer possible to play football ... there are only other hobbies that are reading books especially about OR articles and other heroic stories ... later I will find books, magazines and newspapers from church friends for YS to be able to participate in the transfusion with more fun..."

\section{Counseling Process Informant 3 (Family of AJ's Father, RM's Mother)}

\section{Background}

RA children since grade 5 elementary school, have suffered thalassemia since the age of 5 months. The beginning is known because RA children are always weak and do not want to eat and are very pale. The results of laboratory tests show that a positive RA is declared to have thalassemia. RA is the second child of three siblings, his two siblings do not suffer from thalassemia. Nearly 10 years have had to do a blood transfusion between 1-2 months depending on the condition.

RA children are quiet even if they are invited to talk, they are very responsive in communicating. RA states that he feels sad about his condition, because it must always depend on transfusion. RA often cannot take part in playing activities or other school activities, he only follows routine learning in class. RA was familiar with his illness, he knew that it had to be a routine blood transfusion, if it would not get sick. RA is also aware of his different physical condition from his friends, he said "this stomach continues to grow, hard again, sometimes mocked he said to be pregnant". RA stated that if he was ridiculed he likes to feel sad, and sometimes lazy at school.

Ra's parents are RM's 35-year-old mother and AJ's father is 38 years old. RM's mother is a housewife while AJ's father works in a plastic factory. Ms. RM looks healthy and active everyday taking care of the family. Ms. RM and Mr. AJ were quite communicative and gave a good response to the researchers. Mrs. RM said that her husband seemed to sometimes not care about Ra's condition, as he expressed, "if his father seemed indifferent, he didn't know because Ra now had routine transfusions, so it was rarely asked. the fate of Ra going forward.

\section{Implementation of family counseling}

\section{Building Relationship}


In this process, the researcher introduces himself to the informant (mother and child) and explains the purpose of the arrival / research that will be conducted. Informants from the beginning received happily, even immediately told about family conditions and specifically the illness that their children experienced openly. Researchers showed empathy verbally and non-verbally, so informants eventually became more open and seemed comfortable in the counseling process. Likewise for RA children, researchers show genuine concern, so that RA can respond well.

\section{Disclosure/Depth Search}

Self-active aspect: Ms. RM seemed resigned to accepting Ra's health condition, according to him it might have been fate. Mr. AJ also stated the same thing, that it was fate to have children with thalassemia, they also stated that they did not know the reason why their child suffered from thalassemia, even though doctors stated that thalassemia was a hereditary or hereditary disease. After finding out Ra suffered from RM thalassemia and Mr. AJ followed the doctor's instructions that his child be routinely transfused.

Planning Aspect: Ms. RM and Mr. AJ stated that they would always routinely bring Ra to seek treatment and try to encourage $\mathrm{Ra}$ to want to transfuse and also want to stay in school, although sometimes in despair, as he expressed, "I often feel desperate about Ra's fate, especially if you see his stomach getting bigger and harder, pity to see it, it's a pity he likes to be ridiculed at his school ".

Sepf-control Aspect: Ms. RM stated that if she was sad she would reveal to her husband or to her family (her mother and sister), as he revealed: "I no longer cry a lot now, I have just given up, but the burden of the thought is how the future Ra".

Aspect of seeking social support: Ms. RM said that to reduce anxiety and worry, so often chatting with other families who have children with thalassemia, the time of transfusion for 4 hours, used by Ms. RM to share with other mothers who were waiting for their children transfusions, was also done POPTI management.

Self-acceptance Aspect: Ms. RM felt that it had become destiny if Ra suffered from thalassemia, because the other two children were in good health, but he resignedly accepted all this. Ms. RM stated, "if it is indeed a derivative, my other two children are also healthy, but the doctor said that it is not necessarily all the thalassemia candidates to just happen to be acquainted with Ra". Ms. RM stated further, "hopefully there is a way out later if my child has to be operated on".

Religiosity Aspect: Ms. RM said that it was closer to Allah SWT and also told Ra to diligently pray and pray that Ra could recover, also to have money for medical treatment Ra.

\section{Alternative Solution/Agreement to Act}

The in-depth search results showed that the family as a whole still needs strengthening of the copyng strategy. Ms. RM stated that she often felt scared and anxious about the future of Ra. Mrs. RM sometimes feels hopeless but confused what to do. Likewise, Mr. AJ stated that he did not know what else to do.

Self-active Aspect: Some alternative solutions were discussed with RM's mother and Mr. AJ, such as to overcome the confusion about Ra's disease, so often asked the experts, namely doctors who were at POPTI Foundation, regarding what should be done to help Ra stay healthy and fit. Besides that RM's mother and father AJ must actively participate in the parent group with thalassemia children, sharing experiences among members of the parent association will add insight into how to behave and do the right thing.

Planning Aspect: Ms. RM needs to make or determine what needs to be done to stay calm and in a pleasant atmosphere. Ms. RM understands that there is no point in constantly lamenting fate. Mrs. RM agreed that some attitudes and behaviors must be changed such as not dissolving in emotions such as 
crying or anger or silence without communicating, it will be eliminated and replaced with activeness to communicate with all family members.

Self-control Aspect: Self-control, especially from emotions that sometimes go up and down according to RM's mother, sometimes feeling normal sometimes feels very sad.

Aspect of Seeking Social Support: The ability to survive in difficult situations will be greatly assisted by the support of the closest people. Ms. RM also felt that if anyone gave attention by asking about conditions or just giving words of enthusiasm, such as: "do not despair, trials are the way to get reward". Words or attention from other people made him feel he got happiness. Therefore Ms. RM strongly agreed to share with extended family or friends, to reduce the burden of the mind and relieve negative emotions.

Self-acceptance Aspect: Another situation that often makes you more burden is your most troubled feelings, suffer the most and continue to wonder why everything happened to you. This situation is sometimes felt by the mother of RM. Therefore, researchers conduct disputing irrational beliefs or eliminate negative thoughts and replace them with positive thinking, such as not only the RM mother who experiences it, the members of the POPTI foundation show that many other people also experience the same thing.

Religiosity Aspect: Getting closer to Allah SWT by always praying for ease and strength as well as taking part in religious activities together with neighbors or with POPTI members is an excellent alternative choice.

\section{Results from the Implementation of Family Counseling}

The results of family counseling on all three families showed positive results. The family of $\mathrm{RH}$ and RE mothers and RA children showed that there was a change in their thinking that thalassemia suffered by RA should not make them despair. The thought that not only their families or their children have thalassemia, but others also experience it. Changes in thoughts on the father, mother and children of RA are expected to bring changes to their psychological side.

Commitments that have been agreed with all family members can be a force to improve family strategy. The counseling process is felt by Mr. RH's family and RE's mother providing reinforcement.

The family of JW mother and YS child showed increasing enthusiasm and motivation. This counseling process can also open JW's potential and thinking more openly, he realizes that with the problems that he has faced, it seems the mind is deadlocked. But after trying to be parsed one by one these problems have been brighter and open to thinking about solving the problem. JW intends to increase family finances, JW intends to make snacks that will be taken by his children who are in high school and also make snack cakes which will be sold to church friends and other close neighborhoods.

In the family of RM mother and father of AJ, family members feel more comfortable because they already know what should be done. The counseling process itself was felt to be encouraging because the counselor's attention made the family's feelings lighter and more open. Other results revealed by RM informants that finally the whole family could gather and share with each other what had become hidden feelings or thoughts, so that after the counseling process was felt by informants that they felt relieved. These results indicate that family counseling can be a significant factor that can improve family capacity.

\section{Conclusion and Recommendation}

Based on the results of the research, it can be stated that family counseling can have a positive influence on families with thalassemia children. Family counseling as an intervention that involves all 
family members so that it can: strengthen relationships between family members, provide solutions / problem solving for families, improve family strategy coping, families know what to do and families are committed to mutual support. Some commitments agreed upon by the family are: actively ask other people: doctors, administrators of foundations, friends who also have thalassemia children and want to start looking for information from other sources such as books, magazines, television; always think positively and organize yourself not to display excessive emotions and think about their impact on children; looking for family support / getting closer to the extended family; improve spiritual life: always pray and draw closer to Allah SWT

The process of family counseling requires commitment from all family members, commitment to attend counseling and willingness to openly convey what is felt and thought. Openness allows the counseling process to run smoothly, find the real problem and find alternatives to solve the right problems.

Some recommendations were submitted to the Thalassemia Foundation Sukabumi Branch as follows: Providing family counseling services, which can be provided by the profession of professional social workers or by psychologists. The purpose of family counseling services is to improve the family's ability to develop copyng strategies. Steps that can be taken include designing a family counseling program; determining human resource will be on duty as a counselor ; etermining the schedule for implementing family counseling and the place for conducting counseling; socializing to families who have thalassemia children.

Providing social workers to be more active in conducting home visits and mentoring for families with thalassemia children, so that the purpose of the family counseling program that has been designed can be implemented.

As a preventive effort and reduce the prevalence (the tendency of children with thalassemia to increase) then to all parties, especially health agencies and other agencies to provide counseling to the community related to Thalassemia.

Conducting further research especially in relation to children with thalassemia who often get bullying in their schools, so that support can be made by all parties including friends in their environment.

\section{References}

BACP (British Association for Counselling and Psychotherapy). (2013). Ethical Framework for Good Practice in Counselling and Psychotherapy.BACP: Lutterworth.

Carver, C.S. 1989.Assesing coping strategy : A Theoretically bassed approach. Journal of Personality and Social Psychology

Friedlander, W.A. (1977). Concepts and Methods of Social Work. New Delhi: Prentice Hall of India.

Geldard, K., \& Geldard, D. (2011). Konseling Anak-Anak. Yogyakarta: Pustaka Pelajar.

Haditono, S.R., Knoers, A.M.P., Monks, F.J. 1996. Psikologi Perkembangan Pengantar dalam berbagai bagiannya. Terjemahan. Yogyakarta: Gadjah Mada University Press.

Hurlock, E. (1980). Psikologi Perkembangan. Jakarta: Erlangga.

J. Moleong. (2004). Penelitian Kualitatif. Bandung: PT. Rosdakarya

Kirkbride, Rebbeca (2016). Counselling Children and Young People in Private Practice. Karnac. London

Lazarus, R.s. \& Folkman, S.(1984). Stress, Appraisal and Coping. New York: Springler.

Levitsky \& Perls. (1970). Terapi Gestalt: Salah satu pendekatan Bimbingan dan Konseling. Retrieved 17 January 2012 from http://www.belajar konseling.com/berita-164-terapi-gestalt-salah-satupendekatan-bimbingan-dan-konseling.html

Malcompayne (2005). Modern Social Work Theory. Palgrave Macmillan

Moch.Nazir.(1999). Metodologi Penelitian. Jakarta: PT Gramedia.

Mulyana,Deddy. (2003). Metodologi Penelitian Kualitatif: Paradigma Baru Ilmu Komuniasi dan Ilmu Sosial lainnya.Bandung: PT Remaja Rosida Karya. 
Mutadin (2002). Pengelolaan Stress, Palembang Wijaya Pustaka

Nelson, D.L, (1990), Chronic work stressand coping : Longitudinal study and suggested new Directions. Academy of Management Journal, 859- 869

Neukrug, S. Edward. (2007). The World of The Counselor: An Introduction to the Counseling Profession. Belmont: Thomson Higher Education

O’Loughlin, M \& O’Loughlin,S. (2008). Social work with children \& families. Mixed

Petr, Christopher , G. (2004). Social Work with Children and their Families. New York. Oxford University Press

Secasa. (2007). Children and counseling: South Eastern Centre Against Sexual Assault is a service of Southern Health. (retrieved from www.secasa.com, April $29^{\text {th }} 2009$

Sharf, Richard S. (2012). Theories of Psychotherapy and Counceling. Concepts and Cases. Cengage Leearning. Boston

Singgih D. Gunarsa. (1996). Konseling dan Psikoterapi. Jakarta: Gunung Mulia

Skidmore, Rex, A.\& Thackeray.(1994).Introduction to Social Work Practice: New York: Prentice Hall Inc.

Sugiyono. (2007). Memahami Penelitian Kualitatif. Bandung: Alfabeta

Sugiyono. (2007). Metode Penelitian Kuantitatif Kualitatif dan R\&D. Bandung:

Turner, J. Francis. (1978). Psychosocial Therapy. New York: Macmillan Publishing Co

Zastrow, H. Charles. (1999).The Practice Of Social Work (7 Ed). USA: Books/ Cole Publishing Company.

Zulfan Saam. (2014). Psikologi Konseling. Jakarta: PT. Raja Grafindo Persada 